\title{
Population dynamics and management of two cichlid species in the Shatt Al-Arab River, Iraq
}

\begin{abstract}
Abdul-Razak M. Mohamed*
Department of Fisheries and Marine Resources, College of Agriculture, University of Basrah, Iraq

Abdullah N. Abood

Basrah Agriculture Directorate, Ministry of Agriculture, Iraq

*Corresponding author. E-mail: abdul19532001@yahoo.com

Abstract

Cichlids are invasive fish to Iraqi waters and became well established and prevailing in different waters. Despite that, there is no stock assessment study conducted for these fish. So, growth, mortality, recruitment and yield-per-recruit of two cichlid's species; Coptodon zillii and Oreochromis aureus from the Shatt Al-Arab River, Iraq were evaluated from November 2015 to October 2016 using the FiSAT software. A total of 1285C. zillii $(2.9-24.0 \mathrm{~cm} \mathrm{TL})$ and $1353 \mathrm{O}$. aureus $(4.5-25.0 \mathrm{~cm} \mathrm{TL})$ were examined. Length-weight relationships were derived, indicating allometric growth for both species. The growth parameters $\left(L_{\infty}, \mathrm{K}, \mathrm{R}_{\mathrm{n}}, \mathrm{t}_{\mathrm{o}}\right.$ and $\left.\varnothing\right)$ obtained for $C$. zillii were $25.5 \mathrm{~cm}, 0.320,0.212,-0.793$ and 2.318 , respectively, while for $O$. aureus were $27.8,0.490,0.214,-0.271$ and 2.578 , respectively. The annual rate of total mortality $(Z)$, fishing $(F)$ and natural $(M)$ for $C$. zillii was found to be $1.51,0.84$ and 0.68 respectively, and for $O$. aureus $2.49,1.08$ and 1.41 , respectively. The present exploitation rates ( $E_{\text {present }}$ ) for $C$. zillii and $O$. aureus were computed to be 0.454 and 0.57 , respectively. Lengths at first capture $\left(L_{C}\right)$ were $12.97 \mathrm{~cm}$ for $C$. zillii and $13.25 \mathrm{~cm}$ for $O$. aureus. The peaks of recruitment of $C$. zillii and $O$. aureus were from February to May and May to July, respectively. The $E_{\text {present }}$ for $C$. zillii and $O$. aureus were below the biological target reference points $\left(F_{0.1}\right.$ and $\left.F_{\max }\right)$, indicating that these species were not overexploited. For management purposes, more yields could be obtained by an increase in the fishing activities on cichlids.
\end{abstract}

Keywords: Cichlids, Growth, Mortality, Shatt Al-Arab River, Yield-per-recruit

\section{Article Info}

https://doi.org/10.31018/

jans.vi.2293

Received: May 14, 2020

Revised: June 6, 2020

Accepted: June 10, 2020

\section{How to Cite}

Mohamed A.R.M. and Abood, A.N. (2020). Population dynamics and management of two cichlid species in the Shatt Al-Arab River, Iraq. Journal of Applied and Natural Science, 12(2): 261 - 269 https://doi.org/10.31018/ jans.vi.2293

\section{INTRODUCTION}

The family Cichlidae plays an important role in commercial fisheries and aquaculture worldwide. The total landing of cichlids fish in the world was about 1.6 ton million tons in 2016 (FAO, 2018), and it was the second most important fish in fish farming in the world after carps, with a production of 6.3 million tons in 2018 (FAO, 2019). There are three major taxonomic groups of tilapia, namely Oreochromis, Sarotherodon and Coptodon (Tilapia), each includes many species including Nile tilapia Oreochromis niloticus, blue tilapia $O$. aureus, gililean tilapia (Sarotherodon galilaeus) and redbelly tilapia Coptodon zillii (McAndrews, 2000). Tilapias are native to Africa and the southwestern Middle East, inhabit a variety of fresh and less commonly brackish water habitats, from shallow streams and ponds through the rivers, lakes and estuaries (Uneke, 2015).

C. zillii and $O$. aureus are widely introduced into different waters all over the world as a food fish or as a control of aquatic vegetation. C. zillii can tol- erate a wide range of salinity at 10 to $30 \%$ (ElSayed, 2006), while O. aureus at up to $20 \%$ (Popma and Masser, 1999). The lower lethal water temperature for most tilapia species is $10-11^{\circ}$ $\mathrm{C}$ for a few days, but the $\mathrm{O}$. aureus tolerates temperatures to about $8^{\circ} \mathrm{C}$ (Popma and Masser, 1999). Several authors have studied the growth, mortality and management of $C$. zilli and $O$. aureus populations in different water bodies in the world using FiSAT II (FAO-ICLARM Stock Assessment Tools) software (Mehanna, 2004; JiménezBadillo, 2006; Mahmoud and Mazrouh, 2008; Messina et al., 2010; Abdul and Omoniyi, 2011; Mahomoud et al., 2011; Mahmoud et al., 2013; El -Bokhty and El-Far, 2014; Uneke and Nwani, 2014). Tilapia species are invasive fish to Iraqi waters in ways that are not known, and early records show that $C$. zilli was caught from the Euphrates River near Musaib City, Centre of Iraq (Saleh, 2007). Now, three tilapia species, O. aureus, C. zillii and $O$. niloticus are well established and dominating in different water bodies of Iraqi. The cichlid's species constituted $21.3 \%$ of fish assemblage in the 
Shatt Al-Arab River during 2015-2016 (Mohamed and Abood, 2017) and $32.3 \%$ of fish assemblage in the same river at Abu Al-Khasib district during 2018-2019 (Mohamed and Hameed, 2019).

However, there is no stock assessment study conducted on these invasive species in Iraqi waters. Therefore, the present work covers growth parameters, mortality rates, probability of capture, recruitment pattern and yield per recruit of the $C$. zillii and $\mathrm{O}$. aureus populations in the Shatt AlArab River, to evaluate the population parameters required for proposing future plans for managing the tilapia stocks in Iraqi waters.

\section{MATERIALS AND METHODS}

Fish sampling: The materials for this study were obtained from three sites on the Shatt Al-Arab River, near Al-Dair Bridge, Abu Al-Khasib district and north Fao town (Fig. 1) from November 2015 to October 2016. The fish was caught using gill nets, cast net and electro-fishing (Mohamed and Abood, 2017).

Growth : The length-frequency data were pooled into a bimonthly period from different stations and subsequently grouped into $1.0 \mathrm{~cm}$ class intervals for analysis. The total length (L) and weight (W) were measured for each species to the nearest 1 $\mathrm{mm}$ and $0.1 \mathrm{~g}$, respectively. The length-weight relationship was estimated for both species by using formula (Le Cren, 1951): $W=a L^{b}$, $a$ and $b$ are constants. The hypothesis of isometric growth (Ricker, 1975) was tested with Student's t-test by using Microsoft Office Excel 2010.

The fitting of the best growth curve was based on the ELEFAN I module implemented in the FAOICLARM Fish Stock Assessment Tools (FiSAT II, ver. 1.2.2.) software (Gayanilo et al. 2005), which allows the fitted curve through the maximum number of peaks of the length-frequency distribution where we find the highest $R_{n}$ value. The estimate of theoretical age at length zero $\left(\mathrm{t}_{0}\right)$ was obtained by using the empirical equation of Pauly (1983):

$\log _{10}\left(-t_{0}\right)=-0.3922-0.275 \log _{10} L \infty-1.0381 \log _{10} K$ ......Eq.1

Growth performance index (ǿ) for each species was computed based on the length data using the following equation (Pauly and Munro, 1984):

$\varnothing^{\prime}=\log _{10} K+2 \log _{10} L_{\infty}$ ......Eq.2

Mortality rates: The instantaneous rate of total mortality $(Z)$ estimated using the length converted catch curve method incorporated in FiSAT package by fitting a regression line through the natural logarithm of the number of fish in various length groups against their relative age. The natural mortality rate (M) was calculated from Pauly's (1980) empirical formula with an input water temperature (T) of $24.6^{\circ} \mathrm{C}$ (Mohamed and Abood, 2017): $\log 10 M=-0.0066-0.279 \log 10 L \infty+0.6543$ $\log 10 \mathrm{~K}+0.463 \log 10 \mathrm{~T}$ ........Eq.3 The fishing mortality $(F)$ for each species was computed as $\mathrm{F}=\mathrm{Z}-\mathrm{M}$ and the current exploitation rate was computed from the rate $F / Z$ (Gulland, 1971).

The probability of capture for each species was calculated by backward extrapolation of the right descending limb of the length converted catch curve using $L \infty$ and $K$ parameters as an input in FiSAT. A selectivity curve was generated using linear regression fitted to the ascending data points from a plot of the probability of capture against length, which was used to derive values of the lengths at capture at probabilities of $0.25\left(\mathrm{~L}_{25}\right)$, $0.5\left(L_{50}\right)$ and $0.75\left(L_{75}\right)$.

Recruitment pattern: Recruitment patterns for each species were obtained by backward projection on the length axis of a set of length-frequency data, and using the growth parameters $L \infty$ and $K$ as described in the FiSAT routine. The peaks and troughs of the graph obtained reflect the seasonality of recruitment.

Yield per recruit ( $\left.Y^{\prime} / R\right)$ and biomass per recruit (B'/R): The relative yield-per-recruit $\left(Y^{\prime} / R\right)$ and relative biomass-per-recruit $\left(B^{\prime} / R\right)$ were estimated for each species by using the knife-edge analysis of Beverton and Holt (1966) as modified by Pauly and Soriano (1986). The calculations were done using the FiSAT software package. The data of $L_{c} /$ $L \infty$ and $M / K$ values were used to estimate $E_{\max }$ (the exploitation rate giving maximum sustainable yield per recruit), $E_{0.1}$ (the exploitation rate at which the marginal increase in relative yield-perrecruit is $10 \%$ of its value at $E=0$, the optimum fishing mortality), and $E_{0.5}$ (the exploitation rate corresponding to $50 \%$ of the unexploited relative biomass per recruit (B'/R)), were estimated. The values of the current exploitation rates and the biological target reference points $\left(F_{0.1}\right.$ and $\left.F_{\max }\right)$ were used to assess the status of $C$. zillii and $O$.

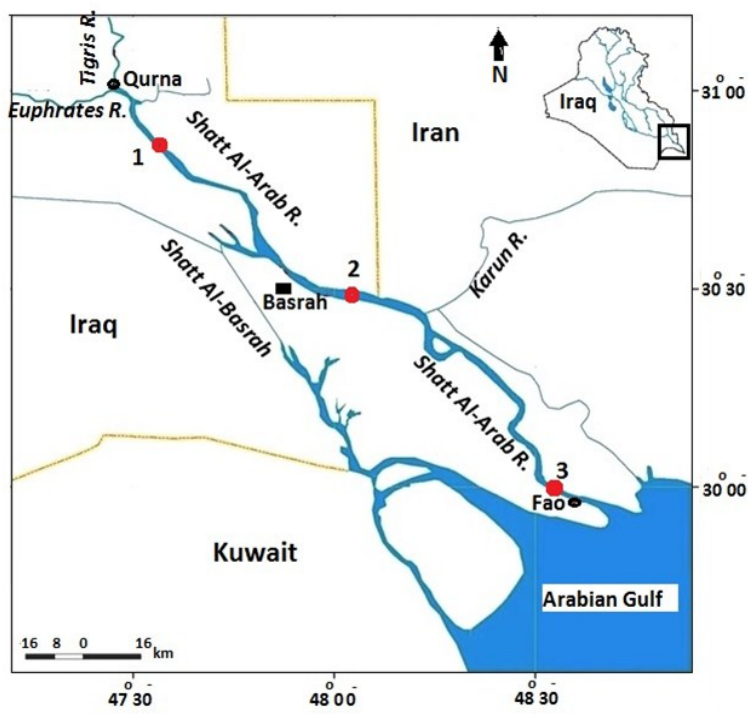

Fig. 1. Map of Shatt Al-Arab with locations of study sites (sketched by the author). 
aureus fisheries in this study (Cadima, 2003).

\section{RESULTS}

Growth parameters: The monthly samples of each species were pooled to produce a single length-frequency distribution to determine the dominant size groups and their percentage composition (Fig. 2). A total of 2638 fish specimens (distributed as 1285 C. zillii and 1353 O. aureus) were involved in this study. The length of fish ranged from 2.9 to $24.0 \mathrm{~cm}$ and their total weight varied between 0.5 and $275.8 \mathrm{~g}$. Fish lengths $11-$ $16 \mathrm{~cm}$ formed $70.7 \%$ of the species caught. The total length of $O$. aureus varied from 4.5 to 25.0 $\mathrm{cm}$ while their total weight ranged between 1.9 and $311.8 \mathrm{~g}$, with fish of $13-16 \mathrm{~cm}$ dominating the catch forming $62.5 \%$ of the species caught.

The length-weight relationships for both species were (Fig. 3):

$\mathrm{W}=0.013 \mathrm{~L}^{3.159}, \mathrm{n}=852,2.9-24.0 \mathrm{~cm}, \mathrm{r}^{2}=0.977$ for $C$. zillii

$\mathrm{W}=0.015 \mathrm{~L}^{3.058}, \quad \mathrm{n}=1082,4.5-25.0 \mathrm{~cm}, \mathrm{r}^{2}=0.929$ for 0 . aureus.

In terms of growth type, both species showed positive allometric growth ( $\mathrm{t}=9.56$ and $2.24, \mathrm{P}<0.05$ ).

The asymptotic length $(L \infty)$ and growth coefficient

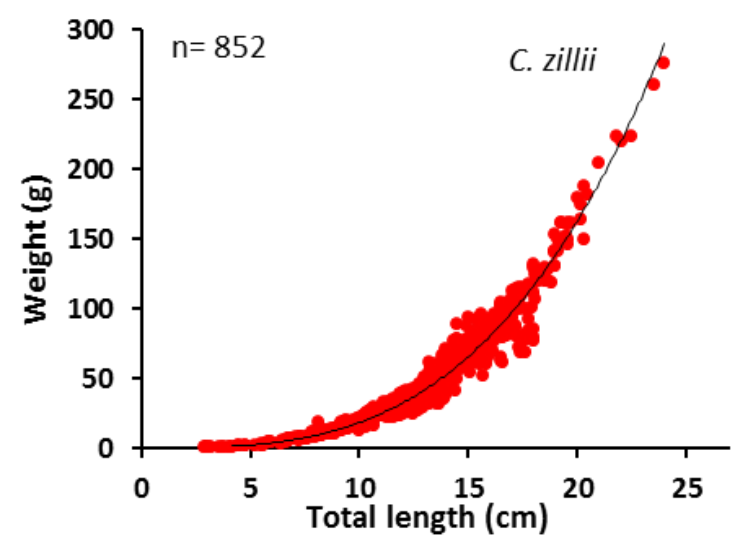

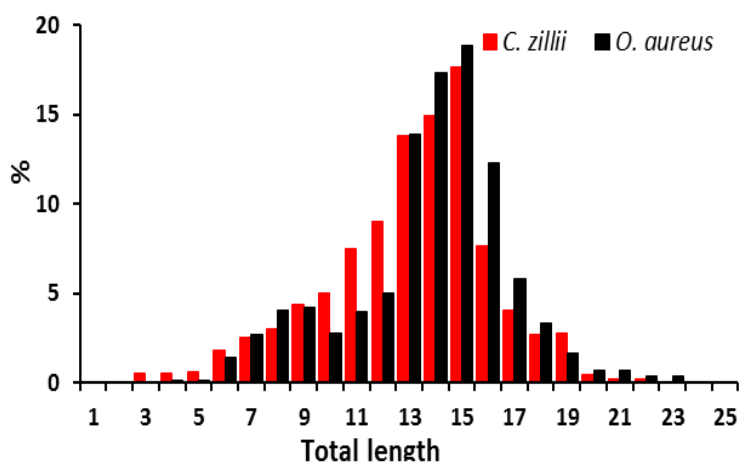

Fig. 2. Overall length frequencies of $C$. zillii and $O$. aureu.s

(K) of for both species from K-scan routine (Fig. 4) were observed by using the direct fit of lengthfrequency data in ELEFAN I and the response surface $\left(R_{n}\right)$ for the von Bertalanffy growth curve (Fig. 5). Therefore, the $L \infty, K$ and $R_{n}$ obtained for C. zillii were $25.5 \mathrm{~cm}, 0.320$ year $^{-1}$ and 0.212 , respectively. The $t_{0}$ was estimated as -0.793 years, and the growth performance index (Ø) was 2.318. The $L \infty, K, R_{n}, t_{0}$ and $\varnothing$ obtained for $O$. aureus were $27.8,0.490,0.214,-0.271$ and 2.578 , respectively. The VBGF for both species could thus

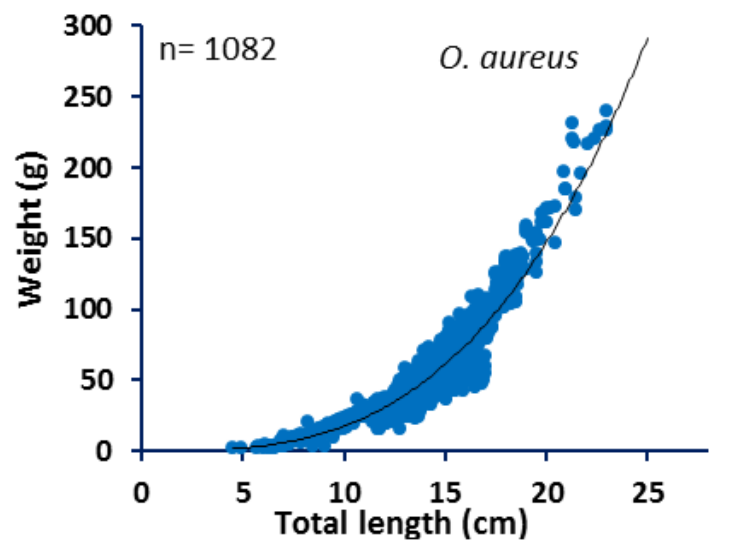

Fig 3. Length-weight relationships of C. zillii and O. aureus.
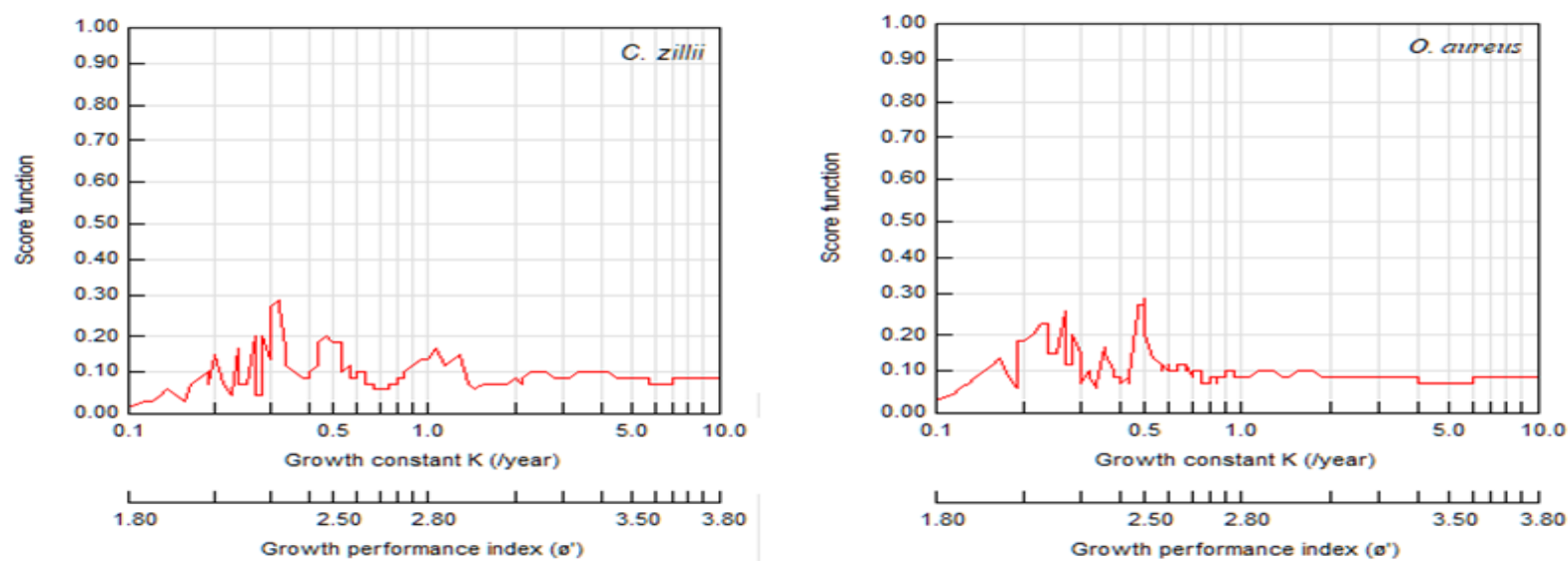

Fig. 4. K-scan routines of C. zillii and O. aureus. 

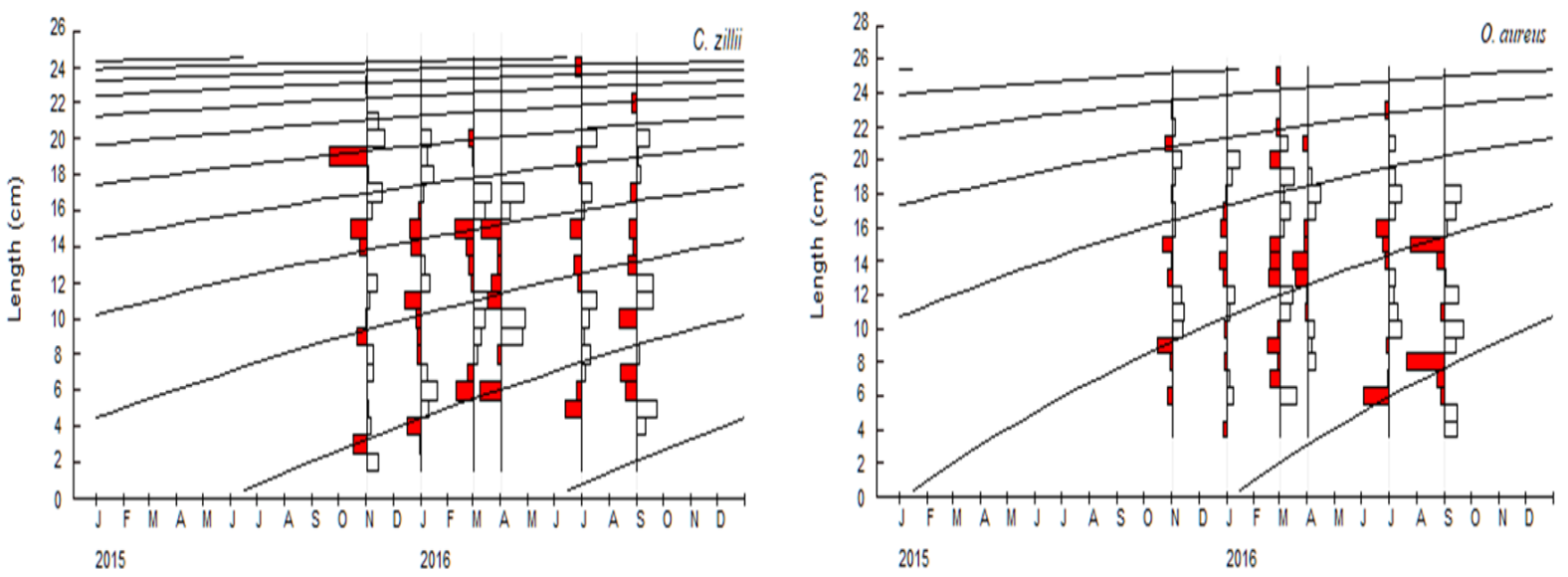

Fig. 5. Restructured length-frequency distribution with growth curves superimposed using ELEFAN-1 for C. zillii and $\mathrm{O}$. aureus.
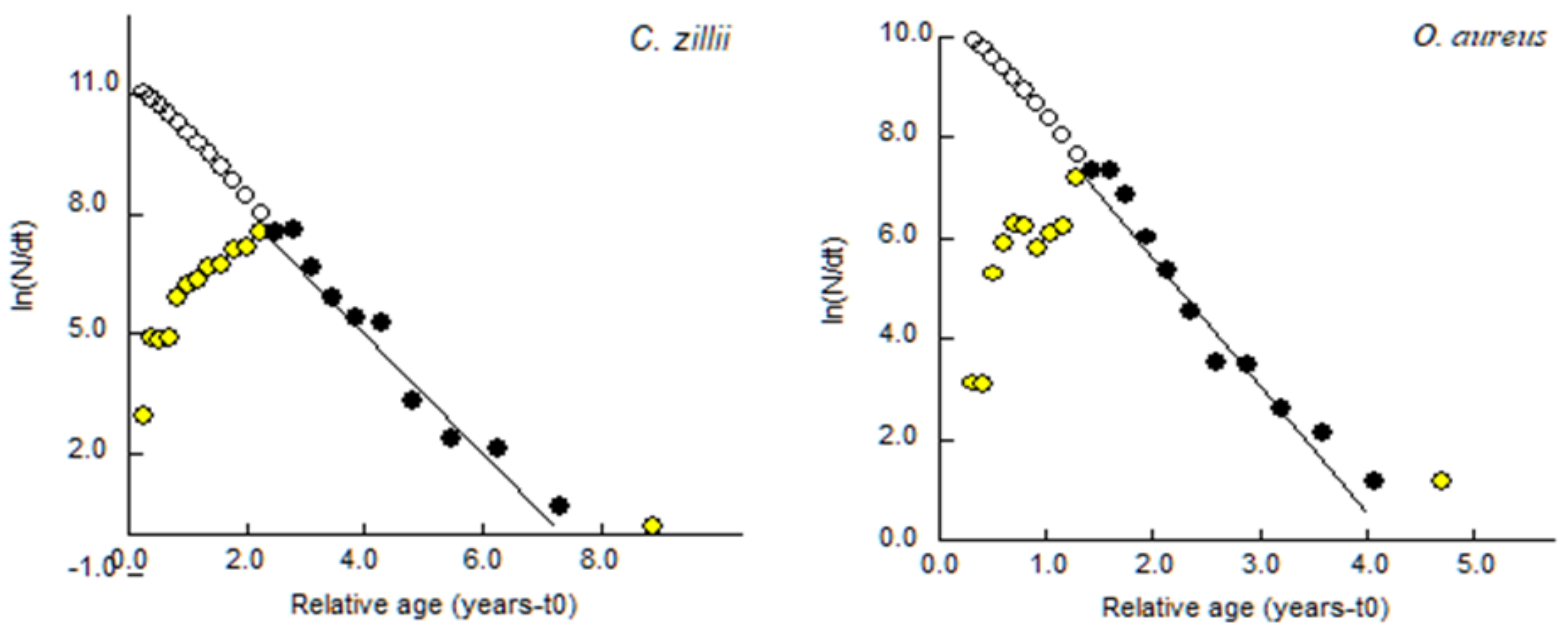

Fig. 6. Length converted catch curves of $C$. zillii and O. aureus.

be written as:

$\mathrm{L}_{\mathrm{t}}=25.5\left(1-\mathrm{e}^{-0.32(\mathrm{t}+0.793)}\right)$ for $C$. zillii

$\mathrm{L}_{\mathrm{t}}=27.8\left(1-\mathrm{e}^{-0.49(\mathrm{t}+0.271)}\right)$ for $\mathrm{O}$. aureus

Mortality and exploitation : Length-converted catch curves of the two species are shown in Fig. 6 . The coefficient of determination $\left(r^{2}\right)$ ranged from 0.967 in $C$. zillii to 0.964 in $O$. aureus. The annual instantaneous rates of total mortality $(Z)$ for C. zillii was 1.51 and for $O$. aureus 2.49 per year. The value of the instantaneous natural mortality coefficient (M) for C. zillii was 0.84 and for $O$. aureus was 1.08. From these results, the fishing mortality coefficient $(F)$ and the present exploitation rate $\left(E_{\text {present }}\right)$ for $C$. zillii were computed to be 0.68 and 0.454 , respectively, and for 0 . aureus 1.41 and 0.57 , respectively.

Probability of capture: Based on the length converted catch curve values, the probability of capture of both species were then analyzed and presented in Fig. 7. The values of $L_{25}, L_{50}$ and $L_{75}$ for C. zillii were found to be $11.32,12.97$ and 14.62 $\mathrm{cm}$, respectively, and for 0 . aureus were 11.65 , 13.25 and $14.84 \mathrm{~cm}$, respectively. Therefore, the length at the first capture " $L_{c}$ " values were 12.97 $\mathrm{cm}$ for $C$. zillii and $13.25 \mathrm{~cm}$ for $O$. aureus.

Recruitment: The recruitment pattern of $C$. zillii was recruited in the fishery from January to July, but exhibited peak between February-May, which account to $63.9 \%$ of the recruits, whereas the recruitment pattern of $O$. aureus was continuous throughout the year, but showed peak between May to July, which constituted $40.5 \%$ of total recruitment throughout the year (Fig. 8).

Yield per recruit ( $\left.Y^{\prime} / R\right)$ and biomass per recruit (B'/R): The relative yield and biomass per recruit analyses for both species were conducted using growth and mortality parameters and selectivity derived from the probability of capture data (Fig. 9 ), indicated that the maximum $\left(Y^{\prime} / R\right)$ was obtained at $E_{\max }=0.938$ for $C$. zillii and $E_{\max }=0.791$ for $O$. aureus. The $E_{0.1}$ and $E_{0.5}$ estimates were 0.751 and 0.376 for $C$. zillii, respectively, whereas 0.668 and 0.361 for $O$. aureus, respectively.

\section{DISCUSSION}

The results revealed that the length-weight relationships for $C$. zillii and $O$. aureus showed positive allometric pattern. In general, Riedel et al. 

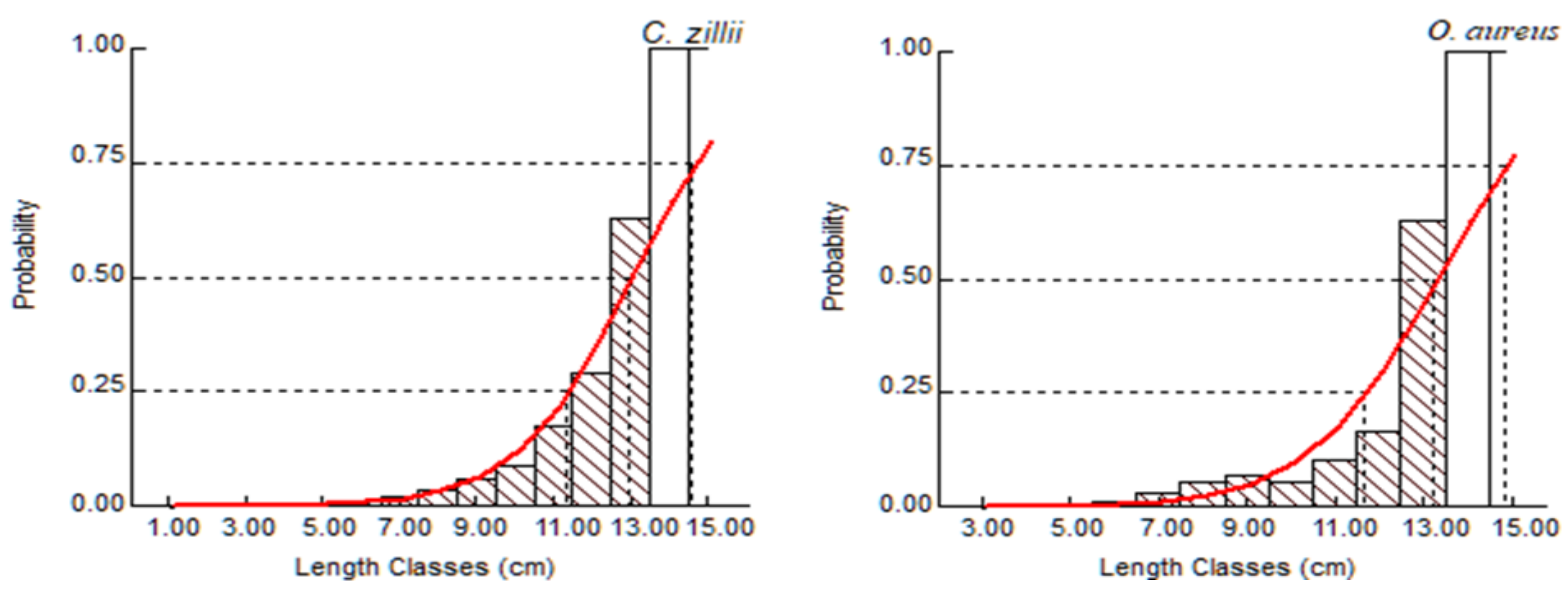

Fig. 7. Probability of capture for C. zillii and O. aureus..
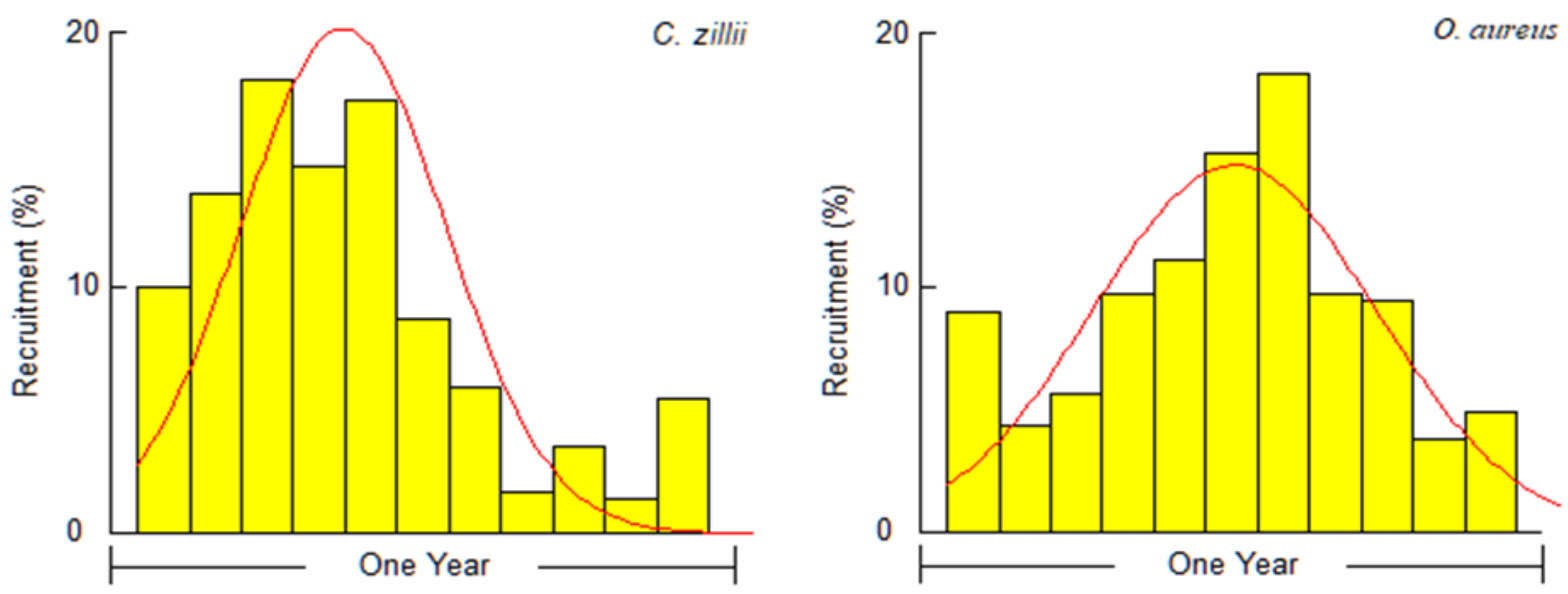

Fig. 8. Recruitment patterns of $C$. zillii and O. aureus.

(2007) stated that the positive allometric growth implies the fish becomes relatively stouter or deeper-bodied as it increases in length

and is indicated by $a b>3.0$. C. zillii showed positive allometric growth in some waters, such as $b=$ 3.228 in Umhfein Lake, Libya (Hadi, 2008), 3.496 in Gbedikere Lake, Nigeria (Adeyemi and Akombo, 2012) and 3.237 in the Garmat Ali River (Mohamed and Al-Wan, 2020). Whereas, some authors reported negative allometric growth for this species in other waters, for example, Negassa and Getahun (2003), Ibrahim et al. (2008), Sholloof (2009), Mahomoud et al. (2011), Mahmoud et al. (2013) and Efitre et al. (2016). However, other studies found isometric growth for $C$. zillii in different waters (Saleh, 1972; Mehanna, 2004; Mahmoud and Mazrouh, 2008). The growth of $O$. aureus also exhibited positive allometric growth in different natural waters in the world, such as in Wadi El-Raiyan Lakes, Egypt (Mehanna, 2004), in Euphrates River, Hindia dam (Hussain et al., 2017), in Pinarbaşi Spring Creek, Turkey (Innal and Giannetto, 2017) and in the Garmat Ali River (Mohamed and Al-Wan, 2020). On the other hand, some authors working on the same species report-

ed negative allometric growth (Jiménez-Badillo, 2006; Mahmoud and Mazrouh, 2008; Messina et al., 2010). These variations could be attributed to various factors like number and size of specimen examined, stomach fullness, sex variation, disease and parasite loads, stage of maturity, the method of sampling and the variations in the environmental conditions among different geographical localities (Bagenal and Tesch, 1978; Gokce et al., 2007; Mir et al., 2012; Cuadrado et al., 2019).

The growth parameters of the von Bertalanffy growth model computed by applying the ELEFAN I module implemented in FiSAT || for the present species are shown in Table 1 along with those reported by other authors for other fish species in various aquatic bodies. In general, the growth and mortality parameters estimated for $O$. aureus were higher than those documented for $C$. zillii in the present study. It is also clear that the values of growth parameters were different among various geographic localities for the same species. The asymptotic length $(L \infty)$ for $C$. zillii in the present study was better than those recorded for the species in some waters (Mahmoud and Mazrouh, 2008; Mahmoud et al., 2011; El-Bokhty and El-Far, 2014), 

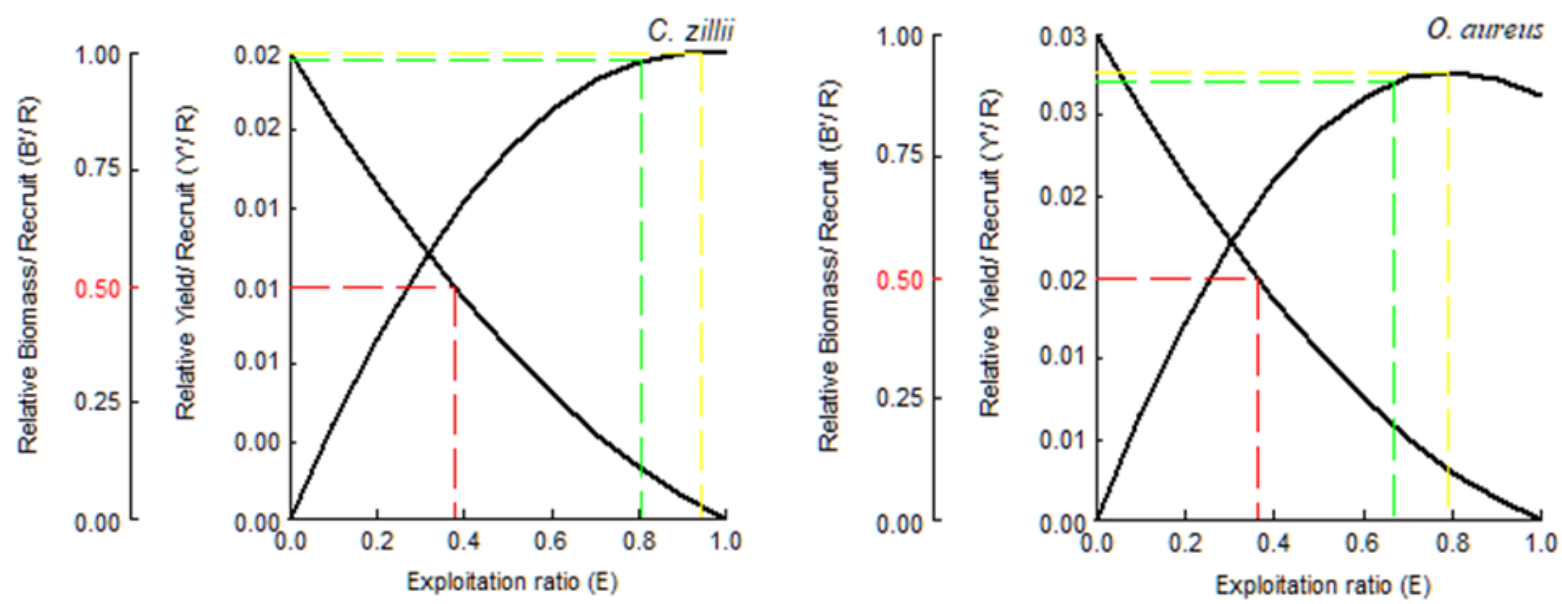

Fig. 9. Relative yield per recruit $\left(Y^{\prime} / R\right)$ and biomass per recruit $\left(B^{\prime} / R\right)$ analyses for $C$. zillii and $O$. aureus.

whereas, it was lower than those found in other waters (Mehanna, 2004; Mahomoud et al., 2013; Uneke and Nwani, 2014). However, Mohamed and Al-Wan (2020) pointed out that the value of $L \infty$ of $C$. zillii in the Garmat Ali River, Iraq was $28.4 \mathrm{~cm}$.

On the other hand, the $L \infty$ value of $O$. aureus in this study was similar to those obtained by Mehanna (2004) for the species in Wadi El-Raiyan Lakes, Egypt and Mahmoud and Mazrouh (2008) in the Rosetta branch of the Nile River, Egypt (Table 1), while it was lower than those reported by Messina et al. (2010) and Mahmoud et al.
(2013) in the Aguamilpa Reservoir, Mexico and the Nozha Hydrodrome, Egypt, respectively. Moreover, $L \infty$ value of $O$. aureus in the Garmat Ali River was found to be $28.4 \mathrm{~cm}$ (Al-wan and Mohamed, 2019).

The values of $K, t_{0}, L_{c}$ and $\varnothing$ of $C$. zillii and $O$. aureus in the present study were intermediate with other values for the two species in other waters (Table 1). This variability in the growth of the same species in different locations could be attributed to several factors, such as ecological conditions, habitat, availability of food, metabolic activity, re-

Table 1. Population parameters of $C$. zillii and $O$. aureus in different aquatic bodies.

\begin{tabular}{|c|c|c|c|c|c|c|c|c|c|c|}
\hline Location & $L \infty$ & $\mathbf{K}$ & $t_{o}$ & $\varnothing$ & $\mathrm{L}_{c}$ & $\mathbf{Z}$ & M & $\mathbf{F}$ & E & Author \\
\hline \multicolumn{11}{|l|}{ C. zillii } \\
\hline $\begin{array}{l}\text { Wadi EL-Raiyan } \\
\text { Lakes, Egypt }\end{array}$ & 33.5 & 0.49 & -0.15 & 2.74 & 11.5 & 1.10 & 0.20 & 0.90 & 0.82 & Mehanna (2004) \\
\hline $\begin{array}{l}\text { Rosetta branch, } \\
\text { Nile River }\end{array}$ & 16.5 & 0.50 & -0.15 & 2.13 & 7.5 & 2.41 & 1.09 & 1.32 & 0.55 & $\begin{array}{l}\text { Mahmoud \& } \\
\text { Mazrouh (2008) }\end{array}$ \\
\hline $\begin{array}{ll}\text { Lake Timsah, } & \mathrm{M} \\
\text { Egypt } & \mathrm{F}\end{array}$ & $\begin{array}{l}22.1 \\
17.8\end{array}$ & $\begin{array}{l}0.32 \\
0.68\end{array}$ & $\begin{array}{l}-1.41 \\
-0.30\end{array}$ & $\begin{array}{l}2.19 \\
2.34\end{array}$ & $\begin{array}{l}- \\
-\end{array}$ & $\begin{array}{l}2.66 \\
1.88\end{array}$ & $\begin{array}{l}0.46 \\
0.38\end{array}$ & $\begin{array}{l}2.19 \\
1.50\end{array}$ & $\begin{array}{l}0.83 \\
0.78\end{array}$ & $\begin{array}{l}\text { Mahomoud et al. } \\
\text { (2011) }\end{array}$ \\
\hline $\begin{array}{l}\text { Nozha } \\
\text { Hydrodrome, } \\
\text { Egypt }\end{array}$ & 33.4 & 0.20 & -0.35 & 2.36 & 13.0 & 0.83 & 0.53 & 0.30 & 0.37 & $\begin{array}{l}\text { Mahmoud et al. } \\
(2013)\end{array}$ \\
\hline $\begin{array}{l}\text { Cross River } \\
\text { basin, Nigeria }\end{array}$ & 27.8 & 0.46 & - & - & 11.9 & 3.16 & 1.14 & 2.02 & 0.64 & $\begin{array}{l}\text { Uneke \& Nwani } \\
\text { (2014) }\end{array}$ \\
\hline $\begin{array}{l}\text { Aswan, Nile } \\
\text { River, Egypt }\end{array}$ & 19.4 & 1.4 & - & - & 13.4 & 5.60 & 2.38 & 3.22 & 0.57 & $\begin{array}{l}\text { El-Bokhty \& El- } \\
\text { Far (2014) }\end{array}$ \\
\hline $\begin{array}{l}\text { Shatt Al-Arab } \\
\text { River } \\
\text { O. aureus }\end{array}$ & 25.5 & 0.32 & -0.79 & 2.32 & 13.0 & 1.51 & 0.84 & 0.68 & 0.45 & Present study \\
\hline $\begin{array}{l}\text { Wadi EL-Raiyan } \\
\text { Wadi EL } \\
\text { Lakes, Egypt }\end{array}$ & 27.2 & 0.56 & -0.32 & 2.62 & 15.3 & 1.69 & 0.25 & 1.44 & 0.85 & Mehanna (2004) \\
\hline $\begin{array}{l}\text { Rosetta branch, } \\
\text { Nile River }\end{array}$ & 26.4 & 0.40 & -0.21 & 2.45 & 10.5 & 2.13 & 0.83 & 1.30 & 0.61 & $\begin{array}{l}\text { Mahmoud \& } \\
\text { Mazrouh (2008) }\end{array}$ \\
\hline $\begin{array}{l}\text { Aguamilpa } \\
\text { Reservoir, Mexico }\end{array}$ & 43.3 & 0.36 & -0.41 & 2.83 & - & 1.94 & 0.83 & 1.10 & 0.57 & $\begin{array}{l}\text { Messina et al. } \\
(2010)\end{array}$ \\
\hline $\begin{array}{l}\text { Nozha } \\
\text { Hydrodrome, } \\
\text { Egypt }\end{array}$ & 38.1 & 0.21 & -0.25 & 2.48 & 13.2 & 0.85 & 0.51 & 0.34 & 0.40 & $\begin{array}{l}\text { Mahmoud et al. } \\
\text { (2013) }\end{array}$ \\
\hline $\begin{array}{l}\text { Shatt Al-Arab } \\
\text { River }\end{array}$ & 27.8 & 0.49 & -0.27 & 2.58 & 13.3 & 2.49 & 1.08 & 1.41 & 0.57 & Present study \\
\hline
\end{tabular}


productive activity, sizes of fish, method of sampling and fishing pressure (Nikolsky, 1963; Shalloof and El-Far, 2009; Mahmoud et al., 2013; Panda et al., 2018). Wootton (2011) stated that the growth of an individual fish achieves on three constraints, the genetic constitution of the individual, the abiotic environment experienced by the fish will set constraints on growth and the biotic environment.

According to the present study, the present exploitation rates $\left(E_{\text {present }}\right)$ were found to be 0.45 as in case of $C$. zillii and 0.57 for $O$. aureus indicating that the $C$. zillii was slightly under the optimum level of exploitation, whereas $O$. aureus was slightly under overexploitation. Gulland (1971) suggested that in an optimal ex-ploited stock, fishing mortality should be about equal to natural mortality, resulting in an exploitation rate of 0.5 , whereas less than 0.5 refers to under exploitation and greater than 0.5 refers to overexploitation. On the other hand, it was found that the exploitation rate of the two species in all the previous studies of different authors (Table 1) are higher than 0.5, except in the Nozha Hydrodrome, Egypt where, it was 0.37 for $C$. zillii and 0.40 for $O$. aureus (Mahmoud et al., 2013), these results indicate that, the stocks of the two species under study are a target species and are suffering from a high rate of exploitation in the different geographic localities.

The recruitment pattern of $C$. zillii was recruited from January to July, but exhibited peak between February-May, whereas the recruitment pattern of $O$. aureus was continuous throughout the year, but showed peak between May to July. JímenezBadillo (2006) mentioned that $O$. aureus have asynchronous spawning, where ovaries do not mature at the same time, but in stages, therefore, the egg liberation takes place sequentially for approximately four months that the spawning period lasts, and the species is a mouthbrooder.

The recruitment of $C$. zillii was found to have two recruitment peaks in a year and the peaks overlapped in time to give a continuous year-round pattern in Bontanga Reservoir, Ghana (KwarfoApegyah and Ofori-Danson, 2010), in the Ogun estuary, Nigeria (Abdul and Omoniyi, 2011) and in the mid-Cross River basin, Nigeria (Uneke and Nwani, 2014). There is no published report on the recruitment of $O$. aureus to the comparison. However, it has been reported that $O$. aureus has two peaks of the gonado-somatic index (GSI) in the Garmat Ali River, Iraq, the highest one was in April thereafter as a sign of the continuous release of eggs, and the second peak in September (Al-Wan and Mohamed, 2019).

Using the knife-edge selection procedure for the analysis of relative yield per recruit and the fishing mortality for $C$. zilli gave an $\mathrm{E}_{\text {present }}=0.454, \mathrm{E}_{0.1}=$ 0.751 and $E_{\max }=0.938$, and for $O$. aureus 0.570 ,
0.668 and 0.791 , respectively. These revealed that both cichlid species understudy did not reach the target reference points, indicating that these species were not over exploited. Similar findings have been observed in $C$. zillii and $O$. aureus stocks in some waters, such as in the Rosetta branch of the Nile River, Egypt (Mahmoud and Mazrouh, 2008), in Ogun estuary, Nigeria (Abdul and Omoniyi, 2011), in Nozha Hydrodrome, Alexandria, Egypt (Mahmoud et al., 2013), in the River Nile, Aswan region, Egypt (El-Bokhty and El-Far, 2014), in the mid-Cross River basin, Nigeria (Uneke and Nwani, 2014). Conversely, other studies found that $C$. zillii and $O$. aureus were overexploited, such as in Wadi El-Raiyan Lakes, Egypt (Mehanna, 2004), in the Aguamilpa Reservoir, Mexico (Messina et al., 2010), in the Lake Timsah, Egypt (Mahomoud et al., 2011).

\section{Conclusion}

The invasive cichlid species are now well established and dominated species in many Iraqi waters. However, the tilapias are not popular table fish in Iraq may be due to their novelty in waters of Iraq or their relatively unimportant sizes compared to exotic and indigenous cyprinids. Moreover, the stocks of tilapias in this study did not reach the target reference points, indicating that these species were not being overexploited. For management purposes, more yields could be obtained by the increase in the fishing activities on tilapias, such as increasing the number of fishing boats and decreasing the mesh-size for substantial harvest for their use as animal forage or export.

\section{REFERENCES}

1. Abdul WO and Omoniyi IT. (2011). Recruitment pattern, probability of capture and predicted yields of Tilapia zillii in Ogun estuary, Nigeria. Journal of Agricultural Science and Environment, 11(2): 90-102.

2. Adeyemi SO and Akombo PM. (2012). A growth and mortality rate of dominant cichlids in Gbedikere Lake, Kogi State, Nigeria. Animal Research International, 9 (1): 1497-1501.

3. Al-Wan SM and Mohamed ARM. (2019). Analysis of the biological features of the blue tilapia, Oreochromis aureus in the Garmat Ali River, Basrah, Iraq. Asian Journal of Applied Sciences, 7(6): 776-787.

4. Bagenal TB and Tesch FW. (1978). "Age and growth. In: Methods for assessment of fish production in freshwater (Bagenal TB. Ed.)". Blackwell Sci. Inc, 101 -130 .

5. Beverton RJH and Holt SJ. (1966). Manual of methods for fish stock assessment. Part II. Fish. Biol. Tech. Pap., 38: 10-67.

6. Cadima EL. (2003). "Fish stock assessment manual". FAO Fisheries Technical Paper. No. 393. Rome, FAO. 161p.

7. Cuadrado JT, Lim DS, Alcontin RMS, Calang JL and Jumawan JC. (2019). Species composition and length-weight relationship of twelve fish species in the two lakes of Esperanza, Agusan del Sur, Philippines. FishTaxa, 4(1) : 1-8. 
8. Efitre J, Murie DJ and Chapman LJ. (2016). Age validation, growth and mortality of introduced Tilapia zillii in Crater Lake Nkuruba, Uganda. Fisheries Management and Ecology, 23: 66-75. DOI: 10.1111/fme.12163.

9. El-Bokhty EEB and EI-Far AM. (2014). Evaluation of Oreochromis niloticus and Tilapia zillii fisheries at Aswan region, River Nile, Egypt. Egypt. J. Aquat. Biol. Fish., 18(3): 79-89. DOI: 10.21608/ ejabf.2014.2220.

10.El-Sayed AFM. (2006). "Tilapia culture". CABI Publishing, Wallingford OX 108 DE. UK. $273 p$.

11.FAO. (2018). "The State of World Fisheries and Aquaculture 2018 - Meeting the sustainable development goals". Rome. Licence: CC BY-NC-SA 3.0 IGO.

12.FAO. (2019). "GLOBEFISH Highlights-A quarterly update on world seafood Markets". January 2019 Issue. Food and Agriculture Organization of the United Nations, Rome, Italy.

13. Gayanilo FCJr, Sparre P and Pauly D. (2005). FAOICLARM Stock Assessment Tools II (FiSAT II). Revised version. User's guide. FAO Comp. Info. Ser. (Fisheries), 8: 1-168.

14.Gokce G, Aydin I and Metin C. (2007). Length-weight relationships of 7 fish species from the North Aegean Sea, Turkey. International Journal of Natural and Engineering Sciences, 1: 51-52.

15.Gulland JA. (1971). "Fish resources of the Ocean". Fishing News Books, Surrey, London, England. 255pp.

16. Hadi AA. (2008) Some observations on the age and growth of Tilapia zillii (GERVAIS, 1848) in Umhfein Lake (Libya). J. Sci. Appl., 2: 12-21.

17. Hussain TS, Abu Alheni AKJ, Kati AZJ, Hassan SM, Ali SM and Mohsen AM. (2017). Describe the growth of blue tilapia Oreochromis aureus (Steindachner, 1864) in the Euphrates River/Al-Hindyah barrier. Journal of Tikrit University for Agricultural Sciences, 17: 443-450.

18.Ibrahim SM, Shalloof KASh and Salama HM. (2008). Effect of Environmental Conditions of Abu-Zabal Lake on Some Biological, Histological and Quality Aspects of Fish. Global Veterinaria, 2 (5): 257-270.

19.Innal D and Giannetto D. (2017). Age Structure and length-weight relationship of non-native Redbelly Tilapia Coptodon zillii (Gervais, 1848) (Cichlidae) in the Pınarbaşı Spring Creek (Burdur, Turkey). Acta Zoologica Bulgaria, 9: 111-116.

20.Jiménez-Badillo L. (2006). Age-growth models for tilapia Oreochromis aureus (Perciformes: Cichlidae) of the Infiernillo reservoir, Mexico and reproductive behavior. Revista de Biología Tropical, 54: 577-588.

21.Kwarfo-Apegyah K and Ofori-Danson PK. (2010). Spawning and recruitment patterns of major fish species in Bontanga Reservoir, Ghana, West Africa. Lakes \& Reservoirs Research \& Management, 15(1): 3-14. https://doi.org/10.1111/j.1440- 1770.2010.004 18.x.

22.Le Cren, ED. (1951). The length-weight relationship and seasonal cycle in gonad weight and condition in the perch (Perca fluviatilis). J. Anim. Ecol., 20: 201-219.

23.Mahmoud HH, Ezzat AA, El-Sayed Ali T and El Samman A. (2013). Fisheries management of cichlid fishes in Nozha Hydrodrome, Alexandria, Egypt. Egyptian Journal of Aquatic Research, 39: 283-289. http:// dx.doi.org/10.1016/j.ejar.2013.12.006.

24.Mahmoud M H and Mazrouh MM. (2008). Biology and fisheries management of Tilapia species in Rosetta branch of the Nile River, Egypt. Egyptian J.
Aquat. Res., 34(3): 272-285.

25.Mahomoud WF, Amal MMA, Kamal FEA, Mohamed $\mathrm{R}$ and Magdy MKO. (2011). Reproductive biology and some observation on the age, growth, and management of Tilapia zilli (Gerv, 1848) from Lake Timsah, Egypt. International Journal of Fisheries and Aquaculture 3(2): 15-25.

26.McAndrews BJ (2000). "Evolution, phylogenetic relationships and biogeography. In: Tilapias: Biology and Exploitation (Beveridge MCM and McAndrews BJ (Eds)". Academic Publishers, Dordrecht, The Netherlands, 1-32.

27.Mehanna SF. (2004). Population dynamics of two cichlids, Oreochromis aureus and Tilapia zillii, from Wadi ElRaiyan Lakes. Egypt. Agri. Marine Sci., 9(1): 9-16.

28.Messina EP, Varela RT, Abunader JIV, Mendoza AAO and Arce JM. (2010). Growth, mortality and reproduction of the blue tilapia Oreochromis aureus (Perciformes: Cichlidae) in the Aguamilpa Reservoir, Mexico. Rev. Biol. Trop., 58 (4): 1577-1586. DOI: 10.15517/rbt.v58i4.5432.

29.Mir JI, Shabir R and Mir FA. (2012). Length-Weight Relationship and Condition Factor of Schizopyge curvifrons (Heckel, 1838) from River Jhelum, Kashmir, India. World Journal of Fish and Marine Sciences, 4 (3): 325-329.

30.Mohamed ARM and Abood AN. (2017). Compositional change in fish assemblage structure in the Shatt Al-Arab River, Iraq. Asian Journal of Applied Sciences, 5(5): 944-958.

31.Mohamed ARM and AI-Wan SM. (2020). Evaluation of biological characters of the invasive species, Coptodon zillii in the Garmat Ali River, Basrah, Iraq. International Journal of Fisheries and Aquatic Studies, 8(2): 176-185.

32.Mohamed ARM and Hameed EK. (2019). Impacts of saltwater intrusion on the fish assemblage in the middle part of Shatt Al-Arab River, Iraq. Asian Journal of Applied Sciences, 7(5): 577-586. DOI: 10.24203/ajas.v7i5.5917.

33.Negassa A and Getahun A. (2003). Breeding season, length-weight relationship and condition factor introduced fish, Tilapia zilli Gerv. 1848 (Pisces: Cichlidae) Lake Zwai, Ethiopia. Ethiopian Journal of Science, 26(2): 115-122. DOI: 10.4314/sinet.v26i2.18 207.

34.Nikolsky GV. (1963). "The ecology of fishes". Academic Press, London and New York, 352 pp.

35.Panda D, Mohanty SK, Pattnaik AK, Das S and Karna SK. (2018). Growth, mortality and stock status of mullets (Mugilidae) in Chilika Lake, India. Lakes \& Reservoirs, 2018: 1-13. https://doi.org/10.1111//re.122 05.

36.Pauly D and Munro JL. (1984). Once more on the comparison of growth in fish and invertebrates. ICLARM Fish byte, 2, 21.

37.Pauly D and Soriano ML. (1986). "Some practical extensions to Beverton and Holt's relative yield-perrecruit model. In: The First Asian Fisheries Forum (Maclean JL, Dizon LB and Hosillo LV (Eds.)". Asian Fisheries Society, Manila, 491-496.

38.Pauly D. (1980). On the interrelationships between natural mortality, growth parameters and mean environmental temperature in 175 fish stocks. J. Cons. CIEM, 39(3): 175-192. https://doi.org/10.1093/ icesjms/39.2.175.

39.Pauly D. (1983). Some simple methods for assessment of tropical fish stocks. FAO Fish. Tech. Pap., 234: 52. 
40.Popma T and Masser M. (1999). "Tilapia Life History and Biology". Southern Regional Aquaculture Centre, USA, Publication No. 283.

41.Ricker WE. (1975). Computation and interpretation of biological statistics of fish populations. Bull. Fish. Res. Board. Can., 191: 382 p.

42.Riedel R, Caskey LM and Hurlbert SH. (2007). Length-weight relations and growth rates of dominant fishes of the Salton Sea: implications for predation by fish-eating birds. Lake and Reservoir Management, 23: 528-535. https://doi.org/10.1080/074 38140709354036.

43. Saleh HH. (1972). A comparative study of the lengthweight equation and the condition factor of Tilapia zillii from Lake Mariut, Egypt. Marine Biology, 12: 255-260. https://doi.org/10.1007/BF00346773.

44.Saleh KI. (2007). First recorded of Tilapia zillii (Gervais, 1848), in natural water of Iraq (Tigris River). The First Scientific Conference of Agricultures College, University of Basra, 26-27.

45.Shalloof KA and EI-Far AM. (2009). Age, growth and fishery biology of cichlid spp. In Abu-Zaabal Lakes, Egypt. Egypt J. Aquat. Biol. Fish., 13: 101-116. DOI: 10.21608/ejabf.2009.2035.

46. Shalloof KA. (2009). Some observations on fisheries biology of Tilapia zillii (Gervais, 1848) and Solea vulgaris (Quensel, 1806) in Lake Qarun, Egypt. World Journal of Fish and Marine Sciences, 1(1): 20-28.

47. Uneke BI and Nwani CD. (2014). Stock assessment of Tilapia zilli (Gervais, 1848) (Osteichthyes: Cichlidae) in a Nigerian tropical river basin. Zoology and Ecology, 24(4): 1-8. http://dx.doi.org/10.1080/216580 05.2014 .959283$.

48.Uneke BI. (2015). Condition Factor of Tilapia Species in Ebonyi River, Southeastern Nigeria. International Journal of Biological Sciences and Applications, 2(4): 33-36.

49.Wootton R.J. (2011). "Growth: environmental effects. In: Encyclopedia of fish physiology: from genome to environment (Farrell AP, Ed.)." Elsevier Science Publishing Co. Inc, United States, 1629-1635. 